\title{
The Use of Islamic Literature to Teach Ethical English
}

\author{
Dedi Irwansyah \\ English Language Education Department, State Islamic Institute of (IAIN) Metro, Lampung, Indonesia \\ Andianto \\ English Language Education Department, State Islamic Institute of (IAIN) Metro, Lampung, Indonesia \\ Ahmad Madkur \\ English Language Education Department, State Islamic Institute of (IAIN) Metro, Lampung, Indonesia
}

\begin{abstract}
Ethical English instruction has paved the way for every religion to make its interpretation. From the Islam religion perspective, such interpretation is still under research. This study describes how ethical English instruction takes place in an Indonesian Islamic higher education institution; how literature, particularly Islamic literature, becomes a factor of ethical English instruction; and the students' transformation through ethical English instruction. Applying a content analysis method, this case study involved 60 freshmen students of the English language education program of State Islamic Institute of Metro, Lampung, Indonesia. The research data was drawn from five main data sources, namely interviews, classroom observations, teaching materials, samples of students' works, and questionnaires. This study shows that (1) the use of Islamic literature to teach ethical English in the Indonesian Islamic higher education is potential; (2) text exploitability becomes a dominant factor in ethical English instruction; and (3) a contextualized approach, derived from the existing global approach and local teaching method, transforms the students positively. It is concluded that ethical English teaching within Indonesian Islamic higher education ought to utilize Islamic literature and be conducted through a contextualized approach.
\end{abstract}

Index Terms-Islamic literature, ethical English, text exploitability, teaching approach, Indonesian Islamic higher education

\section{INTRODUCTION}

Ethical English instruction can be approached not only through spiritual education but also through a cultural and artistic approach. The current discussion of ethical English has seen art as a medium to teach spirituality within an English language classroom (Pike, 2015). Islamic literature, as a form of art, has a great potential in teaching ethical English but has not yet been discussed thoroughly. Within the international context, the teaching of English literature has been dominated by Christian values in its connection to ethical English (Showalter, 2012). Within the Indonesian national context, the Hindu religion is reported to have a great influence on the Indonesian literature tradition (Nurgiyantoro \& Efendi, 2017). The use of Islamic literature to teach ethical English in Indonesian Islamic higher education deserves practitioners' and researchers' attention as Indonesia is the most populous Muslim country in the world.

So far, the discussion of the influence of particular religion on ethical English tends to view the ethical foundation in language teaching without defining a specific influence of a particular religion on the construction of ethical English (Bahodirovna \& Kayumovna, 2019; de Waal, 2002; Yandell, 2015; Bowie, 2016; Smith, 2016; Hutchison, 2019; Lewis, 2020). Ethical English tends to discuss normative moral content in language teaching. Pike (2015) urges that the effort to teach children and teenagers cannot be conducted when a common belief is absent in that education standardization cannot be implemented either. The above tendencies make it obvious that ethical English instruction through Islamic literature has not been accommodated by the existing studies.

This article seeks to enrich the discussion of ethical English. It specifically analyses the use of Islamic literature to teach ethical English at Indonesian Islamic higher education (henceforth PTKI or Perguruan Tinggi Keagamaan Islam). More particularly, the aims of this study are formulated into the following research questions: (1) How does ethical English instruction take place in State Islamic Institute (henceforth IAIN or Institut Agama Islam Negeri) Metro Indonesia? (2) How is Islamic literature used as a factor for the success of ethical English instruction? And (3) How does the use of Islamic literature to teach ethical English transform the students of IAIN Metro so that English becomes more than just a tool of communication?

This study is underpinned by three assumptions. First, ethical English instruction through Islamic literature at PTKI is much more successful than through the previously used approaches. Secondly, the success of ethical English instruction through Islamic literature is strongly influenced by the factor of text exploitability. Thirdly, there is a need to 
contextualize the established literature teaching approaches proposed by western scholars to generate a more acceptable teaching approach at PTKI.

\section{LITERATURE REVIEW}

\section{A. Islamic Literature}

To learn literature is to learn the language and culture (Novianti, 2016). Literary work is not merely a text but also a means to convey a certain ideology (Darma, 2019). Literary works are often rooted in religion, while religion has never existed without literature (Boscaljon \& Levinovitz, 2018). Religious values can be excavated from literary works (Madya, 2013). The terms of religious literature and non-religious literature have been risen by scholars. Religious literature centers around the revelation of the purpose of human existence based on religious teaching (Stolberg \& Teece, 2011), while non-religious literature aims to uncover the world based on humanistic values as a substitution for religious values (Boscaljon \& Levinovitz, 2018). In this sense, Islamic literature is religious literature that is aimed at educating Islamic values. It is used to teach English language and Islamic values.

Literature and religion converging into an ideological context are one of the main factors, along with the historical context, which must be considered in the teaching approach (Walder, 2010). Thus, the use of Islamic literary works to teach English in Islam-affiliated educational settings is self-evident. Scholars have spawned a variety of terms for Islamic literary works such as prophetic literature and Islamic literature. Prophetic literature refers to literary works that invite the readers to have an awareness of Allah and humanity (Kuntowijoyo, 2019), while Islamic literature pertains to any kind of literary works, written in any language, and by any religious writer, which have aesthetic characteristics and messages in tune with Islamic religion (Irwansyah, 2019). There is no fundamental difference between prophetic literature and Islamic literature. Throughout this paper, the term Islamic literature is used because it is considered to include prophetic literature.

\section{B. Ethical English}

Professional ethics is very necessary to be developed by English teachers. Pike (2011a) points out two main reasons for the development of professional ethics. First, abundant valuable works have been done recently related to the reflection of professional learning of English teachers, especially in the so-termed Initial Teacher Education (ITE) (Stevens, Hodges, Gibbons, Hunt, \& Turvey, 2006; Stevens \& Lowing, 2008). Not only is ethical English concerned with who the teacher is, but it also deals with what the teacher does (Pike, 2011a). Secondly, significant contributions have been made on the importance of teaching poetry in the professional learning of English teachers. Scholars argue that it is important for teachers to write and to respond to poetry (Dymoke, 2003; Dymoke \& Harrison, 2008), and that teachers need to keep on reading because teaching readers are good reading teachers (Cremin, 2011). English teachers should gear themselves toward becoming ethical professionals who teach social justice and ethics to their students (Pike, 2011a). English teachers not only need a model of personal growth of their own as an excuse for their calls, but they are also personally involved with the materials and students (Goodwyn, 1992). In other words, ethical English is directed toward the development of teachers, learners, and the social environment.

Pike (2015) classifies three aspects of ethical English: ethical English as spiritual education, ethical English as moral and character education, and ethical English as religious education. Accordingly, an English teacher plays a role in connecting art and life, and of texts and readers. Teachers should lead the students toward primary experience and secondary imagination world. In his research, Pike (2011b) stated that ethical English instruction in the Taoist community has fostered values of democracy and helped prevent the elimination of humanity. Ethical English instruction has a positive impact on the social life system. For this study, the term ethical English refers to spiritual, religious, and moral and character education.

\section{Text Exploitability}

Ethical English instruction relies heavily on texts and their exploitability. The term 'text exploitability' refers to the availability of resources that support the reading comprehension of a text (Lazar, 2009). The resources include supporting movies in the laboratory, related texts in the library, and experts in certain fields of study. Along with authenticity and readability, text exploitability becomes an important factor behind the improvement of interpretive reading skills (Ling, Tong, \& Jin, 2012). The use of Islamic literature to teach ethical English should be supported by relevant books, audio-visual equipment, and experts in the field.

In the concrete level, text exploitability is spelled out through tasks and activities. Collie \& Slater (1994) propose three types of activities to exploit literary text in a language classroom. First, writing activities in that the students are assigned to produce writing related to the literary text they have read. Second, listening and reading activities where students are tasked to read and listen to literary text by focusing on such aspects as characters, background, and language. Third, oral activities where students are asked to create oral summaries or to perform role plays. These three types of activities need to be adjusted by following learning objectives and classroom conditions.

\section{Contextualized Approach to FL Literature}


The term 'approach' refers to theoretical views underpinning the advantages of using literary texts in language classrooms (Fauziah, 2016; Hwang \& Embi, 2007; Padurean, 2015). While a variety of approaches have been suggested by scholars, this paper discusses the so-termed Comprehensive Approach to FL Literature (Bloemert, Jansen, \& van de Grift, 2016; Bloemert, Paran, Jansen, \& van de Grift, 2017). This approach connects four main approaches in teaching literature, namely: Text Approach, Context Approach, Reader Approach, and Language Approach. The Comprehensive Approach, thus, focuses on texts, contexts, reader responses, and language skill development. While an approach is theoretical in nature, its implementation in the classrooms should be conducted through certain methods, strategies, or techniques.

The implementation of the Comprehensive Approach to FL Literature in Indonesian Islamic higher institutions should accommodate local wisdom embedded in local tradition. Islamic educational institutions in Indonesia have a long tradition of using teaching methods called sorogan and bandongan (Ma'Arif, 2018). The former pertains to an individual, and face-to-face instruction marked by a student's reading aloud or memorization of a given material before the teacher. The latter refers to a collective instruction where a teacher explains the learning materials to all students in the class. This article proposes a term of contextualized approach to FL literature to refer to the implementation of the principles of the Comprehensive Approach through the methods of sorogan and bandongan. Such a contextualized approach is aimed at inculcating Islamic teaching methods, which emphasize Islamic manners (adab), into the instructional process.

\section{METHOD}

This study follows a case study design with an in-depth analysis. A case study is used to describe an instruction process in a particular educational context in great detail (Crocker, 2009), which in this research focuses on how Islamic literature is utilized to teach ethical English. IAIN Metro was chosen as it is under the supervision of the Ministry of Religious Affairs (MoRA) of Indonesia and, as any Islamic higher institution in Indonesia, is supposed to integrate Islamic teaching into all branches of knowledge, including English pedagogy.

Participants. This study involved 60 freshmen students of the English language teaching department of IAIN Metro, Lampung, Indonesia. The setting of the study was two pilot project classes aimed at teaching Islam religion and English through Islamic literature in the academic year of 2019/2020.

Instruments. The primary data of this research was drawn from teaching materials and samples of students' works. The data collection techniques used in this research were a questionnaire, classroom observation, and interview. The research data were analyzed through a content analysis technique.

\section{FINDINGS}

Prior to the study was a questionnaire distribution that is aimed at revealing relevant demographic information of the participants. Table 1. represents the recapitulation of the demographic data.

TABLE 1

DEMOGRAPHIC INFORMATION

\begin{tabular}{|c|c|c|c|}
\hline Variable & Category & $(N=60)$ Frequency & Percent-age $\%$ \\
\hline \multirow[t]{2}{*}{ Gender } & Male & 49 & 81.67 \\
\hline & Female & 11 & 18.33 \\
\hline \multirow[t]{4}{*}{ Age } & 17 & 1 & 1.67 \\
\hline & 18 & 22 & 36.67 \\
\hline & 19 & 33 & 55.00 \\
\hline & 20 & 4 & 6.67 \\
\hline \multirow[t]{3}{*}{ School Background* } & ISHS & 22 & 36.67 \\
\hline & SHS & 29 & 48.33 \\
\hline & VHS & 10 & 16.67 \\
\hline \multirow{6}{*}{$\begin{array}{l}\text { Students' familiarity with the Islamic } \\
\text { teaching that underpinned language } \\
\text { skills and critical awareness }\end{array}$} & Listening & 39 & 65.00 \\
\hline & Speaking & 25 & 41.67 \\
\hline & Reading & 58 & 96.67 \\
\hline & Writing & 8 & 13.33 \\
\hline & Discussion & 16 & 26.67 \\
\hline & Critical Awareness & 11 & 18.33 \\
\hline
\end{tabular}

Remarks:

ISHS (Islamic Senior High School (Madrasah Aliyah))

SHS (Senior High School)

VHS (Vocational High School)

The above information reveals that most students of the English language department at Islamic higher institutions do not graduate from Islamic senior high school. Consequently, most of them are not familiar enough with the Islamic 
teachings underpinning English language skills and critical awareness. In this sense, the learning of ethical English is plausible to support the notion of integrating Islamic teachings and English.

\section{A. Ethical English Instruction through Islamic Literature}

Ethical English instruction is part of the efforts to integrate Islamic religion and English language education at PTKI. The use of Islamic literature is an approach that is expected to have a positive influence on ethical English teaching through appropriate stages. In this study, ethical English teaching took place through three phases: (1) selecting, (2) reading, and (3) interpreting and reflecting literary works.

First, the selection stage was conducted by the teacher to Islamic literature based on four principles, namely: (a) the text should not be too long so that it can be completed in one meeting; (b) the text should contain moral messages that can be directly attributed to the Qur'an and hadith as the foundations of education at PTKI; (c) the vocabulary and syntax aspects of the text should not be too difficult for most students. However, teachers still need to ensure that the text still contains challenging vocabularies and syntax patterns; and (d) the text has an aspect (language code, cultural code, literary code, background, characters, setting) that can serve as a springboard to elaborating Islamic values and teachings. For example, the word 'dervish' in the story of Dervish in Hell, is a cultural code that can be used as an entry point to discuss the tradition of Sufism in Islam. Table 2. shows the data of the texts used in this research.

TABEL 2

THE ISLAMIC LITERATURE USED

\begin{tabular}{|c|c|c|c|}
\hline No. & Text Title & Length & Challenging vocabularies and expressions for the students \\
\hline 1. & $\begin{array}{l}\text { The Sterile Woman } \\
\text { (Shah, 1974) }\end{array}$ & 153 words & $\begin{array}{l}\text { Doctor and physician; his wife was not bearing children; come about; } \\
\text { put her off her food; knew; cured }\end{array}$ \\
\hline 2. & $\begin{array}{l}\text { Dervish in Hell (Shah, } \\
\text { 1974) }\end{array}$ & 62 words & $\begin{array}{l}\text { Dervish; exclaimed; reversed; compromised; heaven and paradise; a } \\
\text { voice answered }\end{array}$ \\
\hline 3. & $\begin{array}{l}\text { An Ugly Picture (Clark \& } \\
\text { MacLean, 2004) }\end{array}$ & 70 words & $\begin{array}{l}\text { Noticed; walked; threw; walking down the street; walked over; threw } \\
\text { it away }\end{array}$ \\
\hline 4. & $\begin{array}{l}\text { A Rich Muslim } \\
\text { (Mello, 1991) }\end{array}$ & 76 words & $\begin{array}{l}\text { Took off his expensive shoes; the shoes were gone; thoughtless; } \\
\text { responsible for; I would have gladly given them to him. }\end{array}$ \\
\hline 5. & $\begin{array}{l}\text { The Golden Axe (Kasser \& } \\
\text { Silverman, 1986) }\end{array}$ & 314 words & $\begin{array}{l}\text { Lived; called; dropped; appeared; disappeared; returned; showed; } \\
\text { brought; honest; dishonest; a bridge over a small river; by accident; } \\
\text { on purpose; ...that one wasn't his, either }\end{array}$ \\
\hline 6. & $\begin{array}{l}\text { Justifying Wrong Action } \\
\text { (Vakil \& Vakil, 2011) }\end{array}$ & 395 words & Mosque; Imam Ja'far; the needy; the poor; accomplish \\
\hline
\end{tabular}

The participants of this research tend to look at the pronunciation aspects of the past tense of irregular verbs as challenges. The affixes of past tense -ed on such irregular verbs as walked, called and returned are pronounced [Id] rather than $[\mathrm{t}$ ] or [d]. Idiomatic expressions, synonyms, and cultural codes, such as dervish, are also still challenging for most students. Concerning the meaning aspect, the length of the text tends to have no effect on the students. Short texts such as Dervish in Hell and An Ugly Picture tend to more difficult to understand compared to the longer text like Justifying Wrong Action.

Secondly, the Islamic literature reading stage was conducted through two methods: bandongan (whole class) and sorogan (face-to-face). Bandongan method worked at the collective level and was implemented through the strategy of choral reading and close reading. Choral reading is reading aloud together. Its main objective was to reduce the students' anxiety and to provide examples (modelling) related to acceptable pronunciation and intonation. Close reading was conducted by thoroughly reading a text by presenting morphological, syntactic, and semantic explanations. The objective of close reading was to strengthen the understanding of the aspects of meaning. Meanwhile, the sorogan method worked at the individual level and was used to evaluate the individual achievement of students in terms of pronunciation and text comprehension. In the case of time constraints, sorogan method was conducted randomly, which was by choosing students with a low level of English proficiency.

Thirdly, the interpreting and reflecting stages were carried out through the scheme of take-home assignments so that students had more time to make written answers. A take-home assignment followed not all texts. Before the take-home assignment, students had read several texts so that they could select one of the most-liked texts to be reflected. The task included four main things that students needed to provide, namely (a) specifying the title of the selected text; (b) stating the reason for the selection of the text; (c) providing the message of the text; and (d) listing the Qur'anic verse or hadits relevant to the message of the text. In connection with the assignment, a student wrote: "Because I love fiction, and The Golden Axe is fiction with an outstanding message. The Islamic moral of this story is that honesty will be replied with kindness, and will surely always be close to Allah SWT. It is in line with the hadits narrated by Bukhari and Muslim, stating that 'verily honesty leads to goodness, and goodness leads to paradise (Jihan Lestari, Female, 19 years old, 2020). It appears that the students could respond to the assignment of interpretation and reflection well.

It is noteworthy that all the stages, as mentioned above, were participatory. Any dialogue or discussion on a specific issue rising during the instructional process was placed within the frame of 'appropriate or inappropriate'. The teacher avoided putting the discussion within the evaluative basis of 'correct or incorrect' to create a participatory-dialogical atmosphere.

\section{B. Islamic Literature as a Factor for the Success of Ethical English Instruction}


The use of Islamic literature to teach ethical English had made three successful learning achievements, namely: increasing students' interest in learning, improving students' participation, and enhancing students' language mastery and language skills.

The first success of increasing students' interest in learning was seen in the performance of opening prayer. At this stage, Islamic literature was presented in Arabic with an English translation. It is worth noting that the definition of literature in this study followed the opinion stating that religious texts are literary texts (Maley, 2012), in that texts derived from Qur'an and hadits are seen as literary text. Among the prayers presented in this study were: "Subhanaka la' ilma lana 'illa ma 'allamtana 'innaka 'antal- 'Alimul Hakim." (Holy-Quran, Al-Baqarah 2: 32) with the meaning 'we have no knowledge except what You have taught us. Indeed, it is You who is the Knowing, the Wise.' Another opening prayer was "Allahumma inni a'udhu bika min 'ilmin la yanfa'u, wa qalbin la yakhsha'u, wa nafsin la tashba'u. wa du'a'in la yasma'u" with the meaning' O Allah, I seek refuge with You from knowledge that is not beneficial, a heart that is not humble, a soul that is not satisfied, and a prayer that is not heard.' The use of such prayers is in line with the basic essence of ethical English that requires a spirituality experience in English language learning. The interview data shows a positive response from the student: "So while learning Arabic next to it there is English" [Kurniatul Hasanah, Female, 19 years old, 2020]. It appears that students are interested in and feel benefited with the opening prayers presenting in Arabic and English.

The second success is seen in the increasing participation of the students during the learning activities. The use of short texts with both badongan and sorogan methods proved effective in the students' participation. Concerning religious texts used the opening of the learning activities, most students read them seriously using choral reading and bandongan method. From the very beginning of the instruction, the teacher had to tell the students that according to Islamic teaching, the learning process should begin with prayer performance unless it would lose its blessing aspect. It is worth noting that the use of short text with a span of 50-100 words allowed each student to read it individually before the teacher through the sorogan method. It was evident that the use of short texts allowed students to have a deep practice.

The third success appears in the development of the students' language mastery and language skills. Language mastery refers to vocabulary and grammar, while language skills pertaining to listening, speaking, reading, and writing (Stern, 1991). Related to the language mastery and language skills, the interview data shows: "Some texts contain difficult vocabularies. However, due to the teaching method used in this class, the hard vocabularies made it easy." (Dinda Solehah, Female, 18 years old, 2020]; "...I like it very much because from one story we can learn grammar, pronunciation, and many more." (Muhammad Ardian, Male, 19 years old, 2020); and "For example, I read The Golden Axe and found the message: do not lie and do not be greedy." (Destika Rahmadani, Female, 19 years old, 2020). It is safe to state that the students are progressing primarily on the vocabulary and comprehension aspects of reading.

It is worthy of note that in the above three successes, the use of Islamic literature is a factor behind the students' cognitive and affective achievement.

\section{The Use of Islamic Literature in Ethical English Instruction: A Transformation}

The use of Islamic literature in ethical English instruction is a unique stimulus to a transformation characterized by a change of attitudes and paradigms. In the attitude aspect, students transform from passive to active students. On the paradigm aspect, students can use language as an instrument for sharing and as a way of doing.

The first transformation is related to the change form passive to active students. Students generally become passive when faced with lengthy text with a less familiar topic of discussion. However, the use of short texts containing Islamic values and packaged in a take-home assignment scheme has increased the activity of the students. One of the texts was Dervish in Hell, consisting of 62 words and tells of the religious leader who was thrown into prison for compromising the ruler, and the ruler who was put into heaven for respecting the religious leader. The story encouraged some students to comment: "Indeed, Allah does not see your appearances and possessions, but He sees your heart and deed" (Nurulita Lutfiana, Female, 18 years old, 2020); "...of the greatest sins...making false testimonies or false statement." (Rosnalita, Female, 19 years old, 2020); "(even) an adulteress who gives drinking a thirsty dog is forgiven for her sins." (Nadila, C.S., Female, 19 years old, 2020); and "Don't judge people from the cover...appearance of a man or woman does not guarantee his or her attitude." (Rika Ayu Lestari, Female, 19 years old, 2020). The variety of comments, which were derived from the Islamic tradition, to the same object, shows a good level of the students' being active.

The second transformation is related to the paradigm of language use from communication ability to sharing and caring capacity. Samples of students' works showed another mastery of language mastery and language skills. The use of the word 'we' in the following examples demonstrates the students' sharing and caring skills: "The message we can draw from the story of The Sterile Woman is that there is really no man...knowing when death comes." (Arif Ridho, Male, 20 years old, 2020); "The message of The Golden Axe is that we must be honest and should not lie." (Muhammad Rafif Dhaifullah, M, 18 years old, 2020); "The moral that we could learn from The Sterile Woman is that: do not despair. Trust God's timing." (Allisa Milani, Female, 19 years old, 2020). The use of the word 'we' in the above quotations implicates the engagement of the writer and the interlocutor for the collective good. Thus, Islamic literature presented in English improves not only the students' linguistic competence but also their awareness of sharing Islamic values.

The third transformation is characterized by the paradigm shift from language as an instrument to language as a way of doing. The language exposure and content of values in literary works, as well as reflection session, had encouraged 
the students to speak up their minds. This could be seen in the students' reflective notes: "I was disappointed with myself for not having the courage to come forward, being a volunteer to read out the text that we students had read together... Nevertheless, I would try harder to get rid of such an attitude." (Nurul Isnaini, Female, 18 years old, 2020); and "I love the methods used in the class because they teach me not only the English language but also the knowledge of life which for some people might be meaningless, but not for me." (Tahta Gilang Adiwissa, Male, 18 years old, 2020). Bandongan method and sorogan method have put the language beyond its instrumentality function as a means of communication. More than that, they also form the configuration of the students' ideas and attitudes.

The above three transformations appear to reinforce that argument that has long been pinned in the advantage of literary work, including Islamic literature, which has a transformative potential of making its readers a better person.

\section{Discussion}

As has been touched upon in the previous section, this study is based on three arguments. The first argument is that the teaching of Ethical English through Islamic literature at PTKI is much more successful than of the approaches that had ever been used. The conformity of the ideological content embedded in Islamic literature is beneficial in two ways. First, Islamic literature reduces potential conflicting values that might be found within the texts used to teach English. Different cultural contents often take a longer time to teach. Secondly, Islamic literature allows the teaching of English and Islamic values to occur at the same time. Consequently, Islamic literature is more readily accepted by the students at PTKI, which in turn guarantees the success of achieving language competence and understanding Islamic teachings.

The above finding of Islamic literature effectiveness in ethical English instruction at PTKI is in tune with two previous studies. The first study reported that the reading of the Bible as standard reading materials had become a best practice among the church-based ESL programs in Australia (Wollongong, 2009). The second study found that the integration of local literature into English language learning in the Philippines students has helped the preservation of students' cultural heritage (Florentino, 2014). In terms of acceptance, the position of Islamic literature in the teaching of ethical English at PTKI is similar to that of Bible and Philippines local literature. Bible is acceptable for Christian schools, local culture is acceptable for Philippines students, and Islamic literature is acceptable for Islamic educational contexts.

The second argument is that the successful teaching of ethical English through Islamic literature is heavily influenced by the text exploitability factor. It is the text exploitability that makes the connection among reader, text, and context closer. The findings of this study suggest the importance of text exploitability contextualization of Islamic literature through an assignment strategy that relates text, reading comprehension, and main sources of Islamic tradition. It is safe to state that text exploitability is a dominant factor in the instruction of ethical English.

The findings of this study are relatively different from existing studies. Keshavarzi (2012) reported that the main factor of successful literary work use for Engish instruction is the use of stimulating and imaginative texts. Meanwhile, Isikli \& Tarakcioglu (2017) found that the main factor in the use of literary works for EFL teaching of school students in Turkey is a curriculum design tailored to the real skills of the students. It appears that differences in the success factors for the use of literary works for English instruction are varied, particular, and contextual.

The third argument deals with the need to contextualize and established a literary teaching approach from the Western world to generate a more acceptable teaching method at PTKI in Indonesia. Madya (2015) had long emphasized that despite the rich benefits of using literature in ELT, English teachers need to adapt or contextualize the existing practices by developing their own activities through experiences. The findings of this study demonstrate integrating Indonesian Muslim local tradition into the Western established teaching methods is a logical way to bridge theoretical gaps and practical aspects. English teachers at PTKI might want to integrate the established approach with sorogan and bandongan methods, as local methods that have previously rooted in the instructional tradition of Islam in Indonesia.

The findings of this study also differ from the reported results of Ann, Yunus, \& Aziz (2016), showing that contentbased approaches as the preferable approach in Malaysian Teaching English as a second or foreign language (TESL) context. Fauziah (2016) reported that within the context of teaching English for young learners in Indonesia, there are three frequently used approaches, namely language-based approach (LBA), reader-response approach (RRA), and information-based approach (IBA). It is safe to state that the suitability of a teaching approach of using literary works to teach English depends much on the educational level and educational setting.

\section{CONCLUSIONS}

Unfortunately, what has been understood about ethical English instruction has not been able to show a comprehensive picture of the integration of Islamic literature through a suitable teaching approach. This study finds that the text exploitability aspect, along with the implementation of a contextualized approach, made ethical English instruction in Indonesian Islamic higher education more meaningful. Contextualization in language learning is an essential factor that conditions teaching and learning activities have a closeness to the students.

The use of Islamic literature with special attention to the text exploitability aspect and through the sorogan and bandongan methods has made it possible to understand more comprehensively the potential of local wisdom. It is local 
wisdom that becomes more contextual when it is adjusted with the global theoretical foundation. Through a contextualized approach, an English teacher could gain new insight related to the effort of bridging theoretical discussion with such practical considerations as educational setting, local text, and local traditions.

Nevertheless, this research is limited to the use of Islamic literature to teach ethical English at one university of PTKI only. The study suggests that advanced studies with diverse territories and university classification need to be conducted. Similarly, the comparison of ethical English instruction within other religious backgrounds is needed to configure a more comprehensive understanding of ethical English discussion.

\section{REFERENCES}

[1] Ann, A. Y. J., Yunus, M. M. Y., \& Aziz, A. A. (2016). ESL trainee teachers' approaches and activities in teaching literature: usage, factors and confidence. In J. Adamson (Ed.), The Asian EFL journal professional teaching articles Indonesian international conference edition 1, 69-85. https://doi.org/10.5151/cidi2017-060

[2] Bahodirovna, A. M., \& Kayumovna, B. M. (2019). Analysis of "spirituality" category and its structure in the English language. International Journal of Innovative Technology and Exploring Engineering, $8(9$ Special Issue 3), $1535-1537$. https://doi.org/10.35940/ijitee.I3320.0789S319.

[3] Bloemert, J., Jansen, E., \& van de Grift, W. (2016). Exploring EFL literature approaches in Dutch secondary education. Language, Culture and Curriculum, 29(2), 169-188. https://doi.org/10.1080/07908318.2015.1136324.

[4] Bloemert, J., Paran, A., Jansen, E., \& van de Grift, W. (2017). Students' perspective on the benefits of EFL literature education. Language Learning Journal, 1-14. https://doi.org/10.1080/09571736.2017.1298149.

[5] Boscaljon, D., \& Levinovitz, A. (2018). Teaching religion and literature. New York: Routledge.

[6] Bowie, R. (2016). Ethical English: teaching and learning in English as spiritual, moral and religious education. British Journal of Educational Studies, 64(3), 411-412. https://doi.org/10.1080/00071005.2016.1210316.

[7] Clark, R. C., \& MacLean, R. (2004). Nasreddin Hodja: Stories to read and retell. Vermont: Pro Lingua Associates.

[8] Collie, J., \& Slater, S. (1994). Literature in the language classroom: a resource book of ideas and activities. Cambridge: Cambridge University Press.

[9] Cremin, T. (2011). Reading teachers/teaching readers. English Drama Media, 19(1), 1-1.

[10] Crocker, R. A. (2009). An introduction to qualitative research. In J. Heigham \& R. A. Croker (Eds.), Qualitative research in applied linguistics: a practical introduction (pp. 3-24). New York: Palgrave Macmillan.

[11] Darma, B. (2019). Pengantar teori sastra. Jakarta: PT Kompas Media Nusantara.

[12] de Waal, E. (2002). Book Review: English Spirituality. Theology, 105(824), 169-171. https://doi.org/10.1177/0040571x0210500233.

[13] Dymoke, S. (2003). Drafting and assessing poetry. London: Paul Chapman Publishing.

[14] Dymoke, S., \& Harrison, J. (2008). Reflective teaching and learning: a guide to professional issues for beginning secondary teachers. London: SAGE Publications.

[15] Fauziah, F. (2016). The approaches to teaching literature for EFL young learners. Journal of English Language Teaching and Linguistics, 1(2), 145-158. https://doi.org/10.21462/jeltl.v1i2.26.

[16] Florentino, L. O. (2014). Integrating local literature in teaching English to first graders under K-12 curriculum. Theory and Practice in Language Studies, 4(7), 1344-1351. https://doi.org/10.4304/tpls.4.7.1344-1351.

[17] Goodwyn, A. (1992). English teachers and the cox models. English in Education, 26(3), 4-10. https://doi.org/10.1111/j.17548845.1992.tb01074.x.

[18] Hutchison, A. M. (2019). Birgitta and late-medieval english spirituality. In A Companion to Birgitta of Sweden (269-288). https://doi.org/10.1163/9789004399877_012.

[19] Hwang, D., \& Embi, M. A. (2007). Approaches employed by secondary school teachers to teaching the literature. Jurnal Pendidik dan Pendidikan, 22, 1-23.

[20] Irwansyah, D. (2019). Islamic Literature: Instructional Strategies in Contemporary Indonesia. Heritage of Nusantara: International Journal of Religious Literature and Heritage, 8(1), 1-17.

[21] Isikli, C., \& Tarakcioglu, A. O. (2017). Investigating problems of English literature teaching to EFL high school students in Turkey with focus on language proficiency. Journal of Language and Linguistic Studies, 13(2), 82-95.

[22] Kasser, C., \& Silverman, A. (1986). Stories we brought with us: begining readings for ESL. New Jersey: Prentice Hall.

[23] Keshavarzi, A. (2012). Use of Literature in Teaching English. Procedia - Social and Behavioral Sciences, 46(February), 554 559. https://doi.org/10.1016/j.sbspro.2012.05.159.

[24] Kuntowijoyo. (2019). Maklumat sastra profetik. Yogyakarta: DIVA Press.

[25] Lazar, G. (2009). Literature and language Teaching: a guide for teachers and trainers. Cambridge: Cambridge University Press.

[26] Lewis, M. (2020). Spirituality and English language teaching. Innovation in Language Learning and Teaching, 14(4), $393-394$. https://doi.org/10.1080/17501229.2019.1591420.

[27] Ling, Y. C., Tong, C. S., \& Jin, N. Y. (2012). Evaluating the ESL reading texts for intermediate learners of English from the perspective of students. Global Journal of Human Social Science, 12(7), 54-60.

[28] Ma'Arif, S. (2018). Education as a foundation of humanity: Learning from the pedagogy of pesantren in Indonesia. Journal of Social Studies Education Research, 9(2), 104-123. https://doi.org/10.17499/jsser.58854.

[29] Madya, S. (2013). Metodologi pengajaran bahasa: dari era prametode sampai era pascametode. Yogyakarta: UNY Prress.

[30] Madya, S. (2015). Maximizing students' learning of English communicative competence through the use of literature. TEFLIN's Regional Seminar in Palembang, 7 February 2015, 1-15. Retrieved from http://staffnew.uny.ac.id/upload/130607014/pendidikan/maximizing-students-learning-cc-thr-use-literature-palembang-7-febr2015-1.pdf (accessed 12/01/2020).

[31] Maley, A. (2012). Literature in language teaching. In L. Alsagoff, S. L. McKay, G. Hu, \& W. A. Renandya (Eds.), Principles and Practices for Teaching English as an International Language (pp. 299-317). New York: Routledge. 
[32] Mello, A. De. (1991). The heart of the enlightened: A book of story meditations. New York: Doubleday.

[33] Mustakim, Salina, S., Mustapha, Ramlee, \& Othman, L. (2014). Teacher's approaches in teaching literature: observations of esl classroom. Malaysian Online Journal of Educational Sciences, 2(4), 35-44.

[34] Novianti, N. (2016). English Literature Teaching: an Indonesian Context. Indonesian Journal of Applied Linguistics, 6(1), 4249. https://doi.org/10.17509/ijal.v6i1.2660.

[35] Nurgiyantoro, B., \& Efendi, A. (2017). Re-actualisation of puppet characters in modern Indonesian fictions of the 21st century. 3L: Language, Linguistics, Literature, 23(2), 141-153. https://doi.org/10.17576/3L-2017-2302-11.

[36] Padurean, A. N. (2015). Approaches To Teaching Literature in Efl Classrooms. Journal of Romanian Literary Studies, (6), 195-200.

[37] Pike, M. (2011a). Ethical english teaching: learning democratic values or living by the tao? Changing English: Studies in Culture and Education, 18(4), 351-359. https://doi.org/10.1080/1358684X.2011.630193.

[38] Pike, M. A. (2011b). Developing as an ethical english teacher: valuing the personal and poetic in professional learning. English in Education, 45(3), 224-235. https://doi.org/10.1111/j.1754-8845.2011.01104.x.

[39] Pike, M. A. (2015). Ethical English: Teaching and learning in English as spiritual, moral and religious education. London: Bloomsbury Publishing Plc.

[40] Shah, I. (1974). The way of the sufi. Canada: Penguin Books.

[41] Showalter, E. (2012). Teaching literature. Malden: Blackwell Publishing.

[42] Smith, L. (2016). Ethical English: Teaching and learning in English as spiritual , moral and religious education. Journal of Education for Teaching, 43(3), 371-372. https://doi.org/10.1080/02607476.2016.1175771.

[43] Stern, S. L. (1991). An integrated approach to literature in ESL/EFL. In M. Celce-murcia (Ed.), Teaching English as a Second or Foreign Language (pp. 328-346). Boston: Heinle \& Heinle Publishers.

[44] Stevens, D., Hodges, G. C., Gibbons, S., Hunt, P., \& Turvey, A. (2006). Transformations in learning and teaching through initial teacher education. Literacy, 40(2), 97-105. https://doi.org/10.1111/j.1467-9345.2006.00438.x.

[45] Stevens, D., \& Lowing, K. (2008). Observer, observed and observations: Initial teacher education english tutors' feedback on lessons taught by student teachers of english. English in Education, 42(2), 182-198. https://doi.org/10.1111/j.17548845.2008.00015.x.

[46] Stolberg, T., \& Teece, G. (2011). Teaching religion and science: Effective pedagogy and practical approaches for RE teachers. New Jersey: Routledge.

[47] Vakil, M. A., \& Vakil, M. A. (2011). 40 sufi comics. Retrieved from http://vakil.org/40-sufi-comics. (accessed 15/01/2020).

[48] Walder, D. (2010). Decolonizing the distance curriculum. In T. Kayalis \& A. Natsina (Eds.), Teaching Literature at a Distance: Open, Online and Blended Learning. London: Continuum International Publishing Group.

[49] Wollongong, E. T. (2009). Reading the bible in ESL classes. Sydney: Anglicare.

[50] Yandell, J. (2015). Ethical English: Teaching and learning in English as spiritual, moral and religious education. Changing English, 22(4), 410-415. https://doi.org/10.1080/1358684X.2015.1109837.

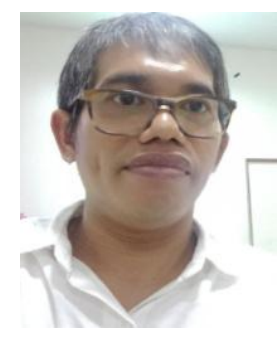

Dedi Irwansyah was born in Sumbawa Besar, December 23, 1979. Pursued his undergraduate degree from English Letters Department of Sanata Dharma University, Yogyakarta in 2002, Masteral degree in Applied Linguistics from Yogyakarta State University (YSU) in 2005, and doctoral degree of Language Educational Science from YSU in 2018.

$\mathrm{He}$ has been teaching English at State Islamic Institute of Metro, Lampung, Indonesia, since 2006. He authored the book of English for Muslim Learners in 2015, published by Penerbit Kalarana Press, Yogyakarta. His current research interests include TEFL and multiculturalism, teaching with literature, and TEFL in Islamic university.

Dr. Irwansyah is a member of Indonesian Researchers for Language Learning and Teaching (iRecall).

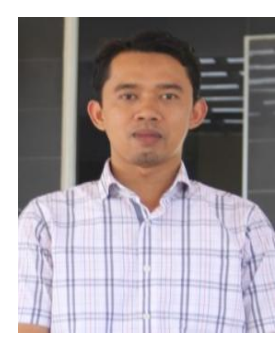

Andianto was born on November 2, 1987, in Bumi Jaya, North Lampung. He earned his undergraduate from English Language Education Department of Muhammadiyah University of Metro in 2010 and master degree in the field of study of English Language Education from Sebelas Maret University in 2013.

$\mathrm{He}$ has been an English teachers educator at State Islamic Institute of Metro, Lampung, Indonesia since 2015. His research interests include TEFL, ELT in Indonesia, and integration of education and technology in language teaching.

Mr. Andianto is a head of the English Language Department of State Islamic Institute of Metro, Lampung, Indonesia since 2021.

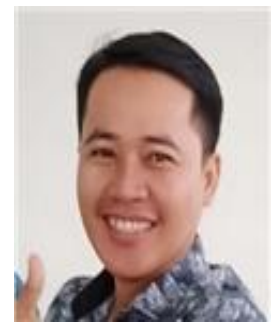

Ahmad Madkur was born on December 6, 1987, in Kalidadi, Central Lampung. He received a bachelor's degree in English Language Teaching from State Islamic Institute of Metro Lampung, Indonesia, in 2012, a master's degree in the same field from Universitas Islam Negeri Syarif Hidayatullah Jakarta in 2015, and is currently pursuing his $\mathrm{PhD}$ at the School of Education, Deakin University Australia.

He has been a lecturer at Faculty of Tarbiya and Teachers Training, State Islamic Institute of Metro Lampung, Indonesia. He co-authored the book "Mastering Basic English Grammar through Islamic Stories" in 2019, published by Laduny Alifatama, Lampung. His research interests include, but are not limited to, teachers' pedagogical beliefs and voices, value integration in English as foreign language teaching, and ELT 
in Islamic boarding school (pesantren) context.

Mr. Madkur is a board member of Indonesian English Lecturers Association (IELA). 